\title{
ISU-ISU SENTRAL PENDIDIKAN DALAM KAITAN PENGEMBANGAN BAHAN AJAR
}

\section{Oleh: Purwanti ${ }^{1}$}

Abstrak

Upaya mempersiapkan keluaran perguruan tinggi yang berkualitas sangat terkait dengan ketersediaan dan kesesuaian berbagai faktor pendudukung. Salah satu diantara komponen pendukung tersebut adalah tersedianya bahan ajar yang aktual yang diangkat dari isu-isu terkini atau isu-isu sentral di dalam berbagai aspek pengetahuan dan informasi, khususnya berkaitan dengan pendidikan. Tulisan ini mengangkat beberapa di antara isu sentral dimaksud, antara lain; isu filosofis, arah baru Pendidikan Kewarganegaraan, konseling lintas budaya \& cyber conseling, perubahan pandangan tentang eksistensi pendidikan nilai, life skills education, multicultural education, beberapa pendekatan pembelajaran berbasis inquiry, dan e learnig.

\section{Kata-kata Kunci: Isu-isu Sentral, Pendidikan, Bahan ajar.}

\section{A. Pendahuluan}

Tuntutan terhadap percepatan peningkatan kualitas pendidikan dan pembelajaran dalam setiap jenjang dan satuan pendidikan menjadi kebutuhan yang sangat mendesak saat ini. Hal ini utamanya didorong oleh demikian cepatnya perubahan-perubahan yang terjadi di luar lembaga pendidikan atau di dalam kehidupan masyarakat sebagai salah satu damapak langsung dari kemajuan ilmu pengetahuan dan teknologi.

Pada lembaga pendidikan tinggi, upaya peningkatan kualitas pembelajaran secara menyeluruh dilakukan melalui berbagai upaya, antara lain pemberian kesempatan kepada para dosen untuk mengikuti pendidikan lanjutan, pembenahan dan pengkajian secara kontinyu kurikulum, penataan administrasi dan organisasi sampai kepada pemutakhiran bahan ajar. Komponen terakhir ini sangat bersentuhan langsung dengan kualitas proses pembelajaran atau perkuliahan yang

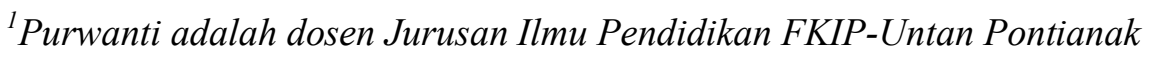


dilaksanakan oleh dosen. Dengan kata lain kualitas perkuliahan yang dilaksanakan atau dikelola oleh dosen akan tercermin dari sejauhmana bahan ajar yang dipergunakan dapat menggambarkan isu-isu aktual yang terjadi pada lingkungannya (lokal maupun global) atau bahan-bahan tersebut tidak usang (out of date).

Selain dari alasan tersebut di atas, kepekaan tenaga pengajar terhadap perkembangan dan perubahan yang terjadi di kaitkan dengan bahan ajar, juga karena suatu alasan bahwa pendidikan yang dilaksanakan saat ini sesungguhnya tidak hanya diarahkan untuk mempersiapkan peserta didik untuk dapat mesrespons kebutuhan saat ini saja, akan tetapi juga mempersiapkan mereka untuk dapat mengantisipasi dan berperan serta di dalam perubahan-perubahan di masa yang akan datang. Kondisi di masa mendatang selayaknya dapat dikaji dari fenomena-fenomena atau trend dinamika perubahan saat ini. Karena itu hampir dapat dipastikan bahwa kemajuan pengetahuan dan teknologi di masa-masa mendatang akan terjadi lebih cepat. Demikian pula arus perubahan sosial dan nilainilai dalam kehidupan sosial masyarakat akan lebih kompleks di banding dengan dinamika perubahan saat ini. Kesemuanya itu menjadi alasan yang kuat sehingga setiap tenaga pengajar khususnya dituntut aktif mencermati dan mengkaji peruban-perubahan yang terjadi, termasuk isu-isu mutakhir yang berkembang.

\section{B. Beberapa Isu Utama Pendidikan 1. Isu Filosofis}

Melalui Seminar Lokakarya Nasional Arah Baru Pengembangan Ilmu Pendidikan (2005), Menteri Pendidikan Nasional memberikan beberapa penegasan kembali terutama tentang isu-isu filosofis pendidikan. Diungkapkan bahwa secara filosofis, pendidikan ditantang untuk melakukan redefinisi tentang tujuan, fungsi, dan hakekat pendidikan yang berperan sebagai "human education for all human being". Pendidikan harus memiliki keseimbangan dalam perannya membangun peserta didik sebagai warga dunia, warga bangsa, dan warga masyarakat. Dengan demikian, maka pendidikan harus dapat membekali pesrta didik untuk dapat mengikuti perkembangan yang terjadi dengan sangat cepat di berbagai belahan dunia. Pada saat yang sama secara praksis pendidikan harus memiliki keterkaitan dengan waktu kekinian dan konteks lokal tempat peserta didik hidup dan dibesarkan. Dengan demikian secara filosofis arah pendidikan harus menyeimbangkan antara perkembangan global di satu sisi dan akar sosial budaya dalam konteks lokal di sisi yang lain. Demikian pula arah pendidikan harus menyeimbangkan antara hal- 
hal yang akan berdimensi masa depan dengan hal yang berdimensi masa kini

Secara substansi, arah pendidikan harus membekali peserta didik dengan kompetensi yang bersifat subject matter dan kompetensi lintas kurikulum (cross- curriculer competencies) yang diperlukan. Kompetensi subject matter berkaitan dengan mata pelajaran yang harus benar-benar dipilih oleh satuan pendidikan sebagai dasar peserta didik untuk memahami dan mengembangkan kompetensi dirinya. Kompetensi lintas kurikulum adalah kompetensi-kompetensi yang dibutuhkan peserta didik sebagai individu, yang baik secara implisit maupun eksplisit terkait dengan berbagai mata pelajaran. Kemampuan lintas kurikulum yang sangat diperlukan antara lain kemampuan memecahkan masalah, komunikasi, hubungan sosial dan interpersonal, kemandirian, etika dan estetika. Kompetensi-kompetensi lintas kurikulum tersebut tidak dapat dipelajari secara spesifik melalui mata pelajaran, tetapi merupakan kemampuan yang diperoleh secara holistik dan integratif antar mata pelajaran. Dalam kehidupan yang semakin kompleks seringkali kompetensi lintas kurikulum merupakan instrumen yang sangat penting untuk dapat bertahan hidup (survival kit).

Perkembangan teknologi informasi dan komuniksi dapat banyak memberikan sumbangana positif bagi perkembangan proses pendidikan. Namun demikian perlu dicermati perkembangan teknologi dan informasi juga pada saat yang sama jangan sampai menimbulkan proses dehumanisasi pendidikan, di mana hubungan sosial personal antara pendidik dan peserta didik terabaikan. Peran teknologi dan informasi dalam proses pendidikan jangan sampai menjadikan peserta didik yang individualistik dengan mengabaikan peran sosial kemasyarakatannya.

Masih dalam pembahasan filosofis, Konstruktivisme sebagai salah satu filsafat pengetahuan melihat bahwa pengetahuan lebih dianggap sebagai suatu proses pembentukan (konstruksi) yang terus menerus, terus berkembang dan berubah (Suparno, 1997:18).

Di dalam pengembangan bahan ajar dan pendekatan pembelajaran, pandangan konstruktivisme menjadi akar penting untuk diperhatikan. Konstruktivisme menekankan bahwa pengetahuan kita adalah konstruksi (bentukan) kita sendiri. Von Glasersfeld (dalam Battencourt, 1989 dan Matthews, 1994) menegaskan bahwa pengetahuan bukanlah suatu tiruan dari 'kenyataan' (realitas). Pengetahuan bukanlah gambaran dari dunia kenyataan yang ada. Pengetahuan selalu merupakan akibat dari suatu konstruksi kognitif kenyataan melalui kegiatan seseorang . Seseorang membentuk skema, kategori, konsep dan struktur pengetahuan 
yang diperlukan untuk pengetahuan. Proses pembentukan ini berjalan terus menerus dengan setiap kali mengadakan reorganisasi karena adanya suatu pemahaman yang baru.

Menurut prinsip konstruktivis, seorang pengajar atau guru berperan sebagai mediator. Penekanannya pada siswa yang belajar, bukan pada didiplin atau guru yang mengajar. Fungsi mediator dan fasilitator adalah; (a) menyediakan pengalaman belajar yang memungkin siswa/mahasiswa bertanggung jawab dalam membuat rancangan, proses, dan penelitian. Jelas, memberi kuliah atau ceramah bukanlah tugas utama seorang guru atau dosen; (b) menyediakan atau memberikan kegiatankegiatan yang merangsang keingintahuan murid dan membantu mereka untuk mengekpresikan gagasan-gagasannya dan mengkomunikasikan ide ilmiah mereka; (c) memonitor, mengevaluasi dan menunjukkan proses berfikir siswa, membantu mengevaluasi hipotesis dan kesimpulan siswa.

\section{Arah Baru PKN/Paradigma Baru}

Dalam mencermati dinamika perubahan dan perkembangan yang terjadi, Pendidikan Kewarganegaraan telah melakukan perubahanperubahan mendasar terutama berkenaan dengan jati diri atau paradigma baru yang pada intinya memberikan arahan;

a. Di dalam proses pembelajaran, siswa bukan hanya berperan atau berkedudukan sebagai objek melainkan menjadi subjek atau kiblat/penjuru seluruh komponen pembelajaran (Student Centered/Base).

b. Program (materi ajar) maupun pola KBM tidak lagi monolitik sentralistik, melainkan multy dimensional \& multy media - sumber.

c. Pembelajaran diarahkan pada proses membelajarkan totalitas diri siswa dengan segala lingkungan belajarnya (fisik-non fisik) ke arah pembinaan potensi diri siswa. Karenanya KBS harus diarahkan kepada 4 proses; learning to know, learning to be, learning to do dan learning to leave together yang melahirkan proses pembekalan pengetahuan, pelatihan aneka variasi media dan sumber serta evaluasinya. Pola ini dalam PKN 2000 dan KBK Kn 2002 dilabel dengan pembelajaran Portofolio.

d. Ajeg dengan pola pembelajaran baru tersebut maka pola evaluasinya juga harus bersifat portopolio.

\section{Konseling Lintas Budaya \& Cyber Conseling}


'Konseling lintas budaya' (cross-cultural counseling, counseling across cultural) adalah konseling yang melibatkan konselor dan klien yang berasal dari latar belakang budaya yang berbeda, dan karena itu proses konseling sangat rawan oleh terjadinya bias-bias budaya (cultural biasaes) pada pihak konselor yang mengakibatkan konseling tidak berjalan efektif. Agar kegiatan konseling dapat berjalan efektif, maka konselor dituntut untuk memiliki kepekaan budaya dan melepaskan diri dari bias-bias budaya, mengerti dan dapat mengapresiasi keragaman budaya serta memiliki keterampilan-keterampilan yang responsif secara kultural. Dari segi ini konseling pada dasarnya merupakan sebuah "perjumpaan budaya" (cultural encounter) antara konselor dan klien yang dilayaninya (Supriadi, 2001:6).

Dampak dari kemudahan mengakses informasi melalui jaringan internet, juga menimbulkan kecenderungan baru dalam konseling yang dikenal dengan Cyber Conseling. Melalui teknik ini komunikasi konselor-klien menggunakan e-mail, tetapi bisa juga secara interaktif (on-line) dan melibatkan lebih dari dua orang.

\section{Perubahan Pandangan tentang Eksistensi Pendidikan Nilai}

Beberapa dasawarsa terakhir terjadi kecenderungan baru di dunia, yaitu tumbuhnya kesadaran terhadap nilai. Kecenderungan ini terjadi secara global yang dapat digambarkan sebagai sebuah titik balik dalam peradaban manusia. Di mana-mana orang-orang berbicara tentang nilai dan dalam banyak kesempatan tema-tema tentang nilai atau yang terkait dengan nilai dibahas. Bahkan untuk bidang yang sebelumnya dianggap "bebas nilai" (value-free) sekalipun, kedudukan dan peran nilai makin banyak diangkat. Sekarang mereka hampir sepakat untuk menyatakan, "there is no such thin the so-called "value free science" (tidak ada yang disebut sains bebas nilai).

Di kalangan ilmuwan sosial yang memang karakternya sangat kental bermuatan nilai, jarang sekali ilmuwan sosial yang mengklaim bahwa bidang ilmu atau kajiannya bebas nilai. Sebagai contoh di dalam bidang psikologi, sulit menemukan lagi ahli pengukuran yang berani mengklaim tes yang bebas nilai budaya (culture-free test).

Titik balik lain yang menempatkan isu-isu tentang nilai sebagai fokus perhatian adalah populernya kecerdasan emosional (Emotional Intelligence/Quotien, EI/EQ dan kecerdasan spiritual (Spiritual Intelligence/Quotient, SI/SQ yang mengambil alih popularitas inteligensi intelektual atau lazim disebut Intelligence Quotient (IQ) yang 
mendominasi arena psikologi sejak dasawarsa kedua abad 20. Dalam beberapa tahun terakhir, banyak buku yang terbit yang membahas topiktopik tersebut.

UNESCO menaruh perhatian yang sangat besar terhadap pendidikan nilai utamanya untuk perdamaian dan harmoni. Melalui AsiaPacific Network of International Education and Values Education (APNIEVE) menerbitkan sebuah buku "Learning to live together in peace and harmony: values education for peace, human rights, democracy, and sustainable development for the Asia-Pacific Region" (Belajar untuk hidup bersama dalam damai dan harmoni: Pendidikan nilai untuk perdamaian, hak-hak asasi manusia, demokrasi dan pembangunan berkelanjutan untuk Asia-Pasifik. Buku ini merupakan bahan untuk calon guru dan peserta didik agar dalam mempersiapkan generasi yang akan datang menjadi generasi yang terus menerus berusaha meninggalkan "kebudayaan perselisihaan/peperangan" menuju "kebudayaan perdamaian". Nilai-nilai budaya yang menjamin kerukunan hidup bersama memang perlu terus menerus diusahakan untuk ditanam, dipupuk dan dikembangkan di dalam diri peserta didik, agar terjamin kehidupan bersama di masa depan yang damai dan harmonis yang menjamin iklim yang kondusif bagi pembaharuan dan pembangunan negara-bangsa kita.

\section{Life Skills Education}

Di dalam penjelasan pasal 26 ayat 3 (USPN No, 20 tahun 2003) ditegaskan bahwa pendidikan kecakapan hidup (life skills) adalah pendidikan yang memberikan kecakapan personal, kecakapan sosial, kecakapan intelektual, dan kecakapan vokasional untuk bekerja atau usaha mandiri. Pernyataan tersebut memberikan penegasan bahwa pelaksanaan life skills tidak sekedar diorientasikan untuk mencapai atau memperoleh keterampilan fungsional saja, akan tetapi secara beriringan harus juga diarahkan untuk mengembangkan kecakapan-kecakapan lain, seperti kecakapan personal, kecakapan sosial, maupun kecakapan intelektual. Dimensi-diemensi ini di dalam kerangka pemberdayaan warga belajar merupakan aspek-aspek esensial yang harus dilihat sebagai satu kesatuan yang utuh.

Urgensi pendidikan keterampilan hidup sangat beralasan. Pendidikan ini tidak pragmentaris menekankan kecerdasan otak, namun juga mengembangkan keterpaduan kognitif, afektif dan psikomotorik. Penyelenggaraan pembelajaran mencakup teori dan praktik nyata 
kehidupan sehari-hari, mengatasi masalah personal, sosial dan pekerjaan. Menurut Goodship (1990) pendidikan keterampilan hidup merupakan suatu program yang berupaya mempersiapkana peserta didik agar dapat terampil hidup secara mandiri dan bermakna (to be skilled for independent and meaningfull living).

\section{Multicultural Education}

Multikultural (multycultural), pluralitas (plurality), keragaman (diversity) merupakan istilah yang seringkali dipergunakan untuk menunjukkan pada realitas kemajemukan untuk mengekpresikan keragaman di dalam mosaik kebudayaan.

Multikulturalisme sebagai paradigma baru merupakan upaya merajut kembali hubungan antar manusia yang akhir-akhir ini seringkali terjerumus pada suasana kehidupan yang konfliktual. Ada sebuah kesadaran yang muncul bahwa diperlukan kepekaan terhadap kenyataan kemajemukan, pluralitas bangsa, baik dalam etnis, agama, budaya hingga orientasi politik.

Kajian ini menempatkan posisi dan peran pendidikan sebagai salah satu lembaga sosial budaya yang memiliki peran sangat strategis, bahwa pendidikan harus dikembangkan atas tatanan dan paradigma bahwa keragaman sosial budaya merupakan aset bagi integrasi sosial. Pendidikan multikultural dikembangkan sebagai model pendidikan dengan tujuan mencegah disintegrasi sosial, dapat mengolah dan mentransformasikan realitas pluralitas menjadi potensi interaksi sosial yang memperkuat daya harmonisasi.

\section{Pendekatan Pembelajaran Berbasis Inquiry dan Cooperative Learning}

a. Inquiry Nilai

Secara sederhana, inkuiri dapat didefinisikan sebagai a seeking for truth, information, or knowledge - seeking information by questioning, yaitu aktivitas mencari kebenaran, informasi atau pengetahuan; atau mencari informasi dengan menyusun sejumlah pertanyaan.

Dalam proses pembelajaran, inkuiri dapat diartikan sebagai aktivitas mempersiapkan situasi bagi peserta didik untuk melakukan eksperimen sendir; dalam arti luas ingin melihat apa yang terjadi, ingin melakukan sesuatu, ingin menggunakan simbol-simbol dan mencari jawaban atas pertanyaan sendiri, menemukan sesuatu, membandingkan 
apa yang ditemukan dengan yang ditemukan orang lain. Joyce, Weil dan Calhoun (2000:170), mengemukakan bahwa keterlibatan peserta didik di dalam inkuiri adalah dengan menghadapkan mereka pada sebuah area penelitian, membantu mereka mengidentifikasi sebuah masalah konseptual dan metodologis yang terdapat di dalam area penelitian dan meminta peserta didik untuk mendisain cara-cara mengatasi masalah.

Di dalam pendidikan nilai, pendekatan inkuiri sangat strategis untuk dikembangkan dalam rangka memberikan pengalaman belajar kepada peserta didik menemukan dan mengembangkan nilai-nilai melalui pengamatan atau penelitian terhadap berbagai peristiwa yang terjadi. Dalam proses menganalisis hasil-hasil inkuiri nilai, pembelajaran dimulai dengan meminta peserta didik untuk; (1) menjelaskan kembali perilaku yang ditampilkan seseorang atau sekelompok orang, (2) menyampaikan pandangan atau argumentasi tentang perilaku yang diamati, (3) menyimpulkan nilai-nilai yang secara implisit melekat pada perilaku yang ditampilkan, (4) membandingkan nilai-nilai tersebut dengan nilai-nilai yang secara personal mereka anut atau pedomani.

\section{b. Group Investigation Model}

Model investigasi kelompok (Group Investigation Model) merupakan salah satu model pembelajaran yang dirancang untuk memberikan pengalaman belajar secara langsung kepada siswa/mahasiswa tentang berbagai aspek spesifik yang terkait langsung dengan bidang tugasnya, dalam bentuk kegiatan penelitian bersama yang dilakukan oleh siswa/mahasiswa pada bidang atau latar tertentu. The Network Scientific Inquiry Resources and Connections (2003:1) melalui pembahasannya mengungkapkan bahwa;

Group investigation is an organizational medium for encouraging and guiding students' involvement in learning. Students actively share in influencing the nature of events in their classroom. By communicating freely and cooperating in planning and carrying out their chosen topic of investigation, they can achieve more than they would as individuals. The final result of the group's work reflects each member's contribution, but it is intellectually richer than work done individually by the same student.

Pendapat di atas memberikan penekanan pada eksistensi investigasi kelompok sebagai wahana untuk mendorong dan membimbing keterlibatan siswa dalam proses pembelajaran. Keterlibatan siswa di 
dalam proses pembelajaran merupakan hal yang sangat esensial karena siswa adalah sentral dari keseluruhan kegiatan pembelajaran. Karena itu kebermaknaan pembelajaran sesungguhnya akan sangat tergantung pada bagaimana kebutuhan siswa dalam memperoleh dan mengembangkan pengetahuan, nilai-nilai, serta pengalaman mereka dapat terpenuhi secara optimal melalui kegiatan pembelajaran yang dilaksanakan. Dengan melakukan investigasi terhadap praktek-praktek pendidikan/pembelajaran secara nyata pada latar tertentu, diharapkan pengetahuan-pengetahuan konseptual dan teoritik yang diperoleh melalui proses pembelajaran di kelas akan dilengkapi dengan pengetahuan-pengetahuan dan nilai-nilai moral yang akan diperoleh melalui pengamatan langsung di sekolah sehingga akan dapat mendukung kemampuan profesional setelah menjadi guru.

Prosedur penerapan model pembelajaran ini didahului dengan penjelasan-penjelasan tentang substansi pendekatan, kemudian bersamabersama mahasiswa menformulasikan aspek-aspek yang menjadi fokus investigasi. Selanjutnya mahasiswa/siswa diorganisasikan ke dalam sejumlah kelompok, serta pembagian tugas dan penentuan sumber-sumber atau perangkat yang diperlukan dalam investigasi. Kegiatan juga diikuti dengan konsolidasi tugas-tugas dalam kelompok, mempersiapkan instrumen-instrumen yang yang diperlukan dan menentukan bersama jadwal secara umum. penganalisisan temuan dan pemaparan hasil/ temuan.

\section{c. Cooperative Learning}

Dalam kajian Brandl (2003: 15) diungkapkan bahwa pembelajaran kooperatif atau kolaboratif diorientasikan pada kegiatan guru dalam merancang kegiatan kelompok bagi siswa-siswa untuk menggantikan model pembelajaran yang terfokus pada sistem ceramah (oral lectures). Dalam kegiatan ini kelompok diberikan materi dan alatalat untuk melakukan penelitian pada topik yang ditentukan, memecahkan masalah dalam mata pelajaran tertentu serta menyajikannya dalam pertemuan kelas.

Feldon (2003: 1), dalam salah satu journal of Education, mengungkapkan bahwa melalui beberapa penelitian antara lain dilakukan oleh Samaha \& Del, (2000; Slavin 1983), disimpulkan bahwa strategi pembelajaran kooperatif dan kolaboratif secara luas memberikan pengaruh pencapaian prestasi akademik dan proses sosialisasi yang baik bagi siswa-siswa di sekolah. Dalam pembahasan tersebut juga dipaparkan 
bahwa lingkungan kelas menunjukkan perubahan dari hari kehari, demikian pula perubahan dan perbedaan antara satu sekolah dan sekolah lain. Dumas, (2003:1), memaparkan hasil penelitian yang menunjukkan bahwa metode cooperative learning dapat membantu guru menemukan cara yang efektif untuk merespon perbedaan-perbedaan siswanya dalam meningkatkan kemampuan akademik serta pemahaman perbedaan budaya. Unsur kunci lainnya adalah kemampuan untuk mengembangkan hubungan sosial yang solid dalam mewujudkan teambuilding activities. Keterampilan-keterampilan sosial ini akan dapat dibangun dengan baik apabila setiap anggota kelompok dapat menerima kelebihan-kelebihan dan kekurangan anggota kelompok lain serta perbedaan-perbedaan lainnya termasuk perbeda-an kebiasaan dan budaya.

Beberapa karakteristik/indikator dari pembelajaran kooperatif yang baik dan benar sebagai berikut; (a) pembelajaran kooperatif adalah group learning activities atau lebih tegas lagi merupakan proses KBS individual siswa melalui group learning atau group learning activities yang mendorong, melibatkan dan menjembatani aktivitas belajar individual, (b) dalam pembelajaran kooperatif akan selalu tampil kerjasama dan saling membantu pertukaran aktivitas atau ide-ide (sharing activities/ideas). Pola "partnership/pasangan kerja" dan "saling menilai/ koreksi menuju keberhasilan" dalam kelompok dan atau antar kelompok menjadi ciri utama pembelajaran kooperatif. Semboyan one for all and all for one serta "satu sukses semua sukses dan satu gagal menjadi tanggung jawab bersama" adalah atribut adanya sharing ideas tadi sekaligus pula membina sense of integrity atau belonging atau sense of responsibility, satu terhadap yang lain, terhadap kelompok dan puncaknya terhadap kita semua. Pernyataan yang sama diungkapkan oleh Dumas (2003: 1) bahwa pembelajaran kooperatif yang memiliki semboyan all for one, one for all menjadi wahana yang sangat penting dalam mewujudkan sinergi sehingga tingkat dan hasil yang dicapai akan lebih besar dibandingkan dengan tanpa bersinergi. (c) pembelajaran kooperatif merupakan proses KBS, yakni siswa aktif secara multi dimensional, melakukan investigating, inquiring, evaluating dan valuing, belajar secara kritis, dialog interaktif dan komunikatif, melakukan proses aktivitas belajar yang kontinu, terpadu, efektif dan produktif; (d) pembelajaran kooperatif mengoptimalisasikan proses dan hasil KBS siswa secara individual, kelompok dan kelas, (e) pembelajaran kooperatif merupakan proses sosialisasi, fungsionalisasi dan pemberdayaan siswa, guru, materi, metode, 
media, sumber dan evaluasi, serta pemberdayaan sekolah terhadap keadaan dan perkembangan the real things.

Secara khusus terdapat berapa nilai tambah pembelajaran kooperatif dilihat dari beberapa dimensi adalah sebagai berikut;

1) Dari sudut program pembelajaran meliputi; materi, metode, media, sumber dan evaluasi, di mana pembelajaran kooperatif menuntut diterapkan pendekatan belajar yang siswasentris, humanistik \& demokratis, multi dimensional (multi domain taksonomik, multi gatra dan multi dimensi waktu). Oleh sebab itu the intended curricullum (kurikulum formal/nasional plus buku teks/paket resmi) menjadi dinamik-fungsional dan sarat kegunaan (meaningfull) karena dihidupkan oleh perancang (guru, penulis) menjadi the proper curricullum (kurikulum yang layak) sesuai dengan acuan keharusan pembelajaran yang layak (bukan hanya tuntutan GBPP dan buku paket).

2) Dari sudut siswa, pembelajaran kooperatif mutlak menuntut perhitungan programatik-prosedural yang sesuai dengan kemampuan siswa dan lingkungan belajarnya (learning invironment) sehingga PKK tersebut dapat dilaksanakan (workable). Dengan kualifikasi yang demikian, maka PKK mampu membelajarkan diri dan dapat dilaksanakan pada kehidupan siswa baik di kelas/sekolah maupun dalam lingkungan belajarnya. Oleh sebab itu pula secara materiil/programatik dan prosedural PKK mampu membina dan meningkatkan serta mengembangkan potensi diri siswa, sekaligus pula memberikan pelatihan pelakonan hidup sebenarnya (learning/life experience).

3) Dari sudut guru, PKK memfungsikan profesi guru sebagai kurikulum hidup (pembinaan dan pengembangan kurikulum), sebagai perencana, pelaksanan, motivator dan lain-lain. Dengan demikian guru bukan hanya sebagai sender yang sekedar menyampaikan apa adanya saja.

\section{E-Learning}

E-learning (electronic Learning) adalah kegiatan belajar asinkronis melalui perangkat elektronik komputer yang tersambungkan ke internet di mana peserta didik berupaya memperoleh bahan belajar yang sesuai denan kebutuhannya (Kamarga, 2001:4). Secara lebih spesifik dapat dijelaskan sebagai berikut;

a. E-learning merupakan penyampaian informasi, komunikasi, pelatihan, pendidikan secara online. 
b. E-learning menyediakan seperangkat alat yang dapat memperkaya nilai belajar secara tradisional sehingga semakin besar peluang menjawab tantangan globalisasi.

c. E-learning tidak berarti menggantikan model belajar klasikal di dalam kelas, tetapi memperkuat model belajar tersebu melalui pengayaan informasi tentang substansi (konten) dan pengembangan teknologi pendidikan.

Di samping sejumlah isu yang dikemukakan sebelumnya, mungkin masih demikian banyak isu-isu penting dan mendasar yang dapat dijadikan sebagai sumber kajian di dalam penyusunan atau pengembangan bahan ajar. Pada prinsipnya kajian terhadap isu-isu baru atau isu-isu perubahan dapat membantu setiap tenaga pengajar guna memperkaya bahan ajar yang disusunnya sehingga isi mata kuliah yang disajikan dapat lebih menarik dan aplikatif bagi semua pihak yang terlibat di dalam proses pembelajaran tersebut.

\section{DAFTAR BACAAN}

Battencourt, A. (1989). What is Constructivism and Why Are They All Talking About It?. Michigan State University.

Brandl, W. (2003). "Life-world" and "Learning Environment:", Some Reflection on Teacher' Professionbalism from a Phenomenological-constructivistic Point of View". (Online). Tersedia: http://www.stif2. mhn.de/homeeconomicsoslo.pdf.

Dumas, A. (2003). "All for one, one for all”. Cooperative Learning: Teaching Student in Small Group: Full Document. (Online). Tersedia: http://www.cde.ca.gov/iasa/ cooplrng2. html.

Feldon, D. (2003). "The Implication of Competing Conceptual Frameworks for the Succes of Collaborative Learning Group: The Source A Journal Education. (Online). Tersedia: http:// www.usc.edu/dept/ education/TheSource/Sp03Feldon. html.

Goodships, J.M. (1990). Life Skills Mastery for Students With Special Need. (Online). Tersedia: http://www.ed.gov/ database/ERIC Digest/Ed321502.html. 
Joyce B., Marshal W,. Calhoun, E. (2000). Models of Teaching ( sixth Ed.). USA: Allyn and Bacon

Kamarga, H. (2001). Manajemen E-Learning: Mengelola Pengetahuan sebagai Komoditas.

Matthews, M. (Ed). (1994). Scienc Teaching. New York: Routledge.

Mendiknas. (2005). Sambutan Dalam Semiloka Nasional Arah Baru Pengembangan Ilmu Pendidikan. Bandung.

Suparno, P. (1997). Filsafat Konstruktivisme Dalam Pendidikan. Yogyakarta: Kanisius.

Supriadi, D. (2001). Konseling Lintas Budaya: Isu-isu dan Relevansinya di Indonesia. Pidato Pengukuhan Jabatan Guru Besar Tetap dalam Bidang Bimbingan Konseling Pendidikan pada Fakultas Ilmu Pendidikan Universitas Pendidikan Indonesia.

The Network Scientific Inquiry Resourcess and Connection. (2003). Group Investigation. (Online). Tersedia: http://www.pwcs.edu/ curriculum/ sol/groupinves.htm.

Undang-undang Sistem Pendidikan Nasional Nomor 20 tahun 2003. 